\title{
Chronic $\mathbf{N}$ deposition alters root respiration-tissue $\mathbf{N}$ relationship in northern hardwood forests
}

\author{
ANDREW J. BURTON*†, JULIE C. JARVEY*, MICKEY P. JARVI*, DONALD R. ZAK† $\$$ and \\ KURT S. PREGITZER \\ *School of Forest Resources and Environmental Science, Michigan Technological University, Houghton, MI 49931, USA, \\ $\dagger$ Ecosystem Science Center, Michigan Technological University, Houghton, MI 49931, USA, $\$$ School of Natural Resources and \\ Environment, University of Michigan, Ann Arbor, MI 48109, USA, §Department of Ecology and Evolutionary Biology, \\ University of Michigan, Ann Arbor, MI 48109, USA, |College of Natural Resources, University of Idaho, Moscow, ID 83844, \\ USA
}

\begin{abstract}
Specific root respiration rates typically increase with increasing tissue $\mathrm{N}$ concentration. As a result, it is often assumed that external factors inducing greater root $\mathrm{N}$ concentration, such as chronic $\mathrm{N}$ deposition, will lead to increased respiration rates. However, enhanced $\mathrm{N}$ availability also alters root biomass, making the ecosystem-level consequences on whole-root-system respiration uncertain. The objective of this study was to determine the effects of chronic experimental $\mathrm{N}$ deposition on root $\mathrm{N}$ concentrations, specific respiration rates, and biomass for four northern hardwood forests in Michigan. Three of the six measurement plots at each location have received experimental $\mathrm{N}$ deposition (3 $\mathrm{g} \mathrm{NO}_{3}^{-}-\mathrm{N} \mathrm{m}^{-2} \mathrm{yr}^{-1}$ ) since 1994. We measured specific root respiration rates and $\mathrm{N}$ concentrations of roots from four size classes $(<0.5,0.5-1,1-2$, and $2-10 \mathrm{~mm})$ at three soil depths $(0-10,10-30$, and 30-50 cm). Root biomass data for the same size classes and soil depths was used in combination with specific respiration rates to assess the response of whole-root-system respiration. Root $\mathrm{N}$ and respiration rate were greater for smaller diameter roots and roots at shallow depths. In addition, root $\mathrm{N}$ concentrations were significantly greater under chronic $\mathrm{N}$ deposition, particularly for larger diameter roots. Specific respiration rates and root biomass were unchanged for all depths and size classes, thus whole-root-system respiration was not altered by chronic $\mathrm{N}$ deposition. Higher root $\mathrm{N}$ concentrations in combination with equivalent specific respiration rates under experimental $\mathrm{N}$ deposition resulted in a lower ratio of respiration to tissue $\mathrm{N}$. These results indicate that relationships between root respiration rate and $\mathrm{N}$ concentration do not hold if $\mathrm{N}$ availability is altered significantly. For these forests, use of the ambient respiration to $\mathrm{N}$ relationship would over-predict actual root system respiration for the chronic $\mathrm{N}$ deposition treatment by $50 \%$.
\end{abstract}

Keywords: Acer saccharum, modeling respiration, root biomass, root system respiration, specific respiration rate

Received 25 April 2011 and accepted 11 July 2011

\section{Introduction}

Strong relationships often exist between plant tissue N concentration and respiration rate (Ryan et al., 1996; Atkinson et al., 2007; Reich et al., 2008). As a result, tissue $\mathrm{N}$ concentration can be used to predict or model tissue respiration rates (e.g. Rastetter et al., 1991; Amthor, 2000; Hanson et al., 2004). For roots, N concentration has explained differences in respiration rate among plant species (Burton et al., 2002; Tjoelker et al., 2005), root size and depth classes (Pregitzer et al., 1998; Desrochers et al., 2002; Chen et al., 2010; Ugawa et al., 2010), and sites with different inherent $\mathrm{N}$ availability (Burton et al., 1996; Zogg et al., 1996).

Increases in soil $\mathrm{N}$ availability can occur with both chronic $\mathrm{N}$ additions and soil warming (Magill et al.,

Correspondence: Andrew J. Burton, tel. + 9064873564 ,

fax + 906487 2915, e-mail: ajburton@mtu.edu
2000; Rustad et al., 2001; Melillo et al., 2002, 2011), leading to speculation that such factors may lead to greater root tissue $\mathrm{N}$ concentration and higher respiration rates (Pregitzer et al., 1998). Indeed, this is what ecosystem models that utilize tissue $\mathrm{N}$-respiration relationships would predict under such situations, unless otherwise constrained. However, empirical evidence supporting such a response is lacking. Several experiments have demonstrated higher root $\mathrm{N}$ concentration in response to chronic $\mathrm{N}$ additions of $5-15 \mathrm{~g} \mathrm{~N} \mathrm{~m}^{-2} \mathrm{yr}^{-1}$ (Magill et al., 2004; Jia et al., 2010), but these did not always result in equivalent increases in root respiration (Jia et al., 2010). In other cases, lower levels of chronic $\mathrm{N}$ inputs had no effect on root $\mathrm{N}$ concentration or respiration rate (Pregitzer et al., 1998). Elevated $N$ availability can also alter ecosystem root biomass, typically reducing it (Haynes \& Gower, 1995; Magill et al., 2004; Bakker et al., 2009; Jia et al., 2010; Zhou et al., 2011). At the ecosystem level, such a response could counteract any 
positive effect of higher tissue $\mathrm{N}$ on specific respiration rates. Thus, net effects of long-term increases in $\mathrm{N}$ availability on total ecosystem root respiration are uncertain.

Herein, we report results of a re-examination of root $\mathrm{N}$ concentration, specific respiration rate and biomass in a long-term $\mathrm{N}$ deposition experiment in which four sugar maple (Acer saccharum Marsh.) dominated northern hardwood forests have received experimental chronic $\mathrm{NO}_{3}^{-}$deposition at a rate of $3 \mathrm{~g} \mathrm{~N} \mathrm{~m}^{-2} \mathrm{yr}^{-1}$ since 1994. Earlier measurements at the study sites have indicated no changes in these parameters in response to the chronic N deposition treatment (Zogg et al., 1996; Pregitzer et al., 1998; Burton et al., 2004). In the present study, we assessed the comprehensive responses across multiple root size classes and depths during the 16th year of the experiment. Respiration and $\mathrm{N}$ concentration of the deeper, larger diameter roots had not been examined in detail since 1996 (Pregitzer et al., 1998). Specific objectives were to determine if: (i) chronic $\mathrm{N}$ deposition had increased root $\mathrm{N}$ concentration, increased root specific respiration rate, or decreased root biomass; (ii) whole-root-system respiration had been altered by chronic $\mathrm{N}$ deposition; and (iii) a common relationship for predicting root respiration from tissue $\mathrm{N}$ was still valid for roots from both the ambient and $\mathrm{N}$ deposition treatments.

\section{Materials and methods}

Our study was conducted at four locations along a 500-km climatic gradient, extending from central Lower Michigan to Upper Michigan. All sites contain second-growth northern hardwood forests on sandy Spodosol soils, dominated by sugar maple (71-91\% of basal area, Table 1). In 2009, the dominant overstory trees were approximately 100 years old, and average basal area was $35 \mathrm{~m}^{2} \mathrm{ha}^{-1}$ (Table 1). At each site, there are three control plots, which receive ambient $\mathrm{N}$ deposition, and three plots that received chronic experimental $\mathrm{N}$ deposition beginning in 1994, with $3 \mathrm{~g} \mathrm{NO}_{3}^{-}-\mathrm{N} \mathrm{m}^{-2} \mathrm{yr}^{-1}$ applied as $\mathrm{NaNO}_{3}$ in six $0.5 \mathrm{~g} \mathrm{~N}$ increments every 4 weeks during the growing season. This treatment simulates elevated atmospheric $\mathrm{N}$ deposition, and represented an addition of 2.5-4 times ambient atmospheric $\mathrm{N}$ deposition (Table 1).

Between 24 July and 5 August 2009, respiration rates were measured using an infrared gas analyzer (IRGA) on roots taken from three soil depth increments $(0-10,10-30$, and 30$50 \mathrm{~cm})$ and sorted into four diameter classes $(<0.5,0.5-1,1-2$, and $2-10 \mathrm{~mm}$ ). One sample was collected per depth and root diameter class from each plot at each site. Soil samples were collected using a 10-cm-diameter by 40 -cm-long steel soil corer (Jurgensen et al., 1977). For the $0-10 \mathrm{~cm}$ depth, the cores were taken beneath the loose litter layer (Oi) and were comprised of Oe and Oa horizon plus mineral soil to a total depth of $10 \mathrm{~cm}$. The corer was then driven to a depth of $30 \mathrm{~cm}$ to collect the sample from the $10-30 \mathrm{~cm}$ depth. Finally, soil was removed from the top $20 \mathrm{~cm}$ of an area surrounding the corer to facilitate driving the corer to a depth of $50 \mathrm{~cm}$ to collect the 30$50 \mathrm{~cm}$ sample.

Live roots were hand sorted from the soil samples and brushed free of adhering soil and organic matter. They were then divided by diameter class, using scissors to separate roots into their respective size classes. Live roots were distinguished by white, cream, red, tan, or brown coloration, a smooth appearance, and, for larger woody roots, a moist, light colored interior. Dead roots were often black or dark brown, were brittle, and had frayed, rough edges. For very fine roots $(<0.5 \mathrm{~mm}$

Table 1 Selected characteristics of four northern hardwood forests in Michigan, USA

\begin{tabular}{|c|c|c|c|c|}
\hline Characteristic & Site A & Site B & Site C & Site D \\
\hline Latitude (N) & $46^{\circ} 52^{\prime}$ & $45^{\circ} 33^{\prime}$ & $44^{\circ} 23^{\prime}$ & $43^{\circ} 40^{\prime}$ \\
\hline Longitude (W) & $88^{\circ} 53^{\prime}$ & $84^{\circ} 51^{\prime}$ & $85^{\circ} 50^{\prime}$ & $86^{\circ} 09^{\prime}$ \\
\hline Basal area $\left(\mathrm{m}^{2} \mathrm{ha}^{-1}\right)$ & 35.7 & 33.6 & 33.9 & 37.7 \\
\hline Sugar maple (\% of basal area) & 91 & 86 & 79 & 71 \\
\hline Mean annual precipitation ${ }^{*}(\mathrm{~mm})$ & 879 & 874 & 913 & 824 \\
\hline Growing season precipitation ${ }^{*}(\mathrm{~mm})$ & 401 & 388 & 393 & 379 \\
\hline Mean annual temperature ${ }^{\dagger}\left({ }^{\circ} \mathrm{C}\right)$ & 4.9 & 6.2 & 7.0 & 7.7 \\
\hline Growing season temperature ${ }^{\dagger}\left({ }^{\circ} \mathrm{C}\right)$ & 15.0 & 16.0 & 16.2 & 16.8 \\
\hline Growing season length ${ }^{\ddagger}$ (days) & 134 & 151 & 155 & 158 \\
\hline Overstory age (2009) & 102 & 96 & 97 & 101 \\
\hline Wet + dry total $\mathrm{N}$ deposition $\left(\mathrm{g} \mathrm{N} \mathrm{m}^{-2} \mathrm{yr}^{-1}\right)^{\S}$ & 0.68 & 0.91 & 1.17 & 1.18 \\
\hline
\end{tabular}

*Mean annual and growing season (May-September) precipitation, for the years 1994-2008, was recorded using weighing rain gages (Model 5-780; Belfort Instrument Co., Baltimore, MD, USA) located in open areas within $5 \mathrm{~km}$ of each site.

${ }^{\dagger}$ Mean annual and growing season (May-September) temperature, for the years 1994-2008, was recorded on site at $2 \mathrm{~m}$ using thermistors, which were read every 30 min throughout the year, with averages recorded every 3 h using data loggers (EasyLogger Models 824 and 925; Data Loggers, Inc., Logan, UT, USA).

*Growing season length, for the years 1994-2008, was determined annually by project personnel, based on visual estimates of $>50 \%$ leaf expansion in the spring and $<75 \%$ of foliage remaining in the fall.

${ }^{\S}$ Data from MacDonald et al. (1992). 
diameter), samples consisted primarily of excised root modules, each containing an intact network of root segments comprised primarily of first, second, and third order roots (see Pregitzer et al., 1998 for an illustration of a typical root network). The $<0.5 \mathrm{~mm}$ roots at these sites have short median lifespans of one to one and a half years (Hendrick \& Pregitzer, 1992; Burton et al., 2000), and thus correspond well to the ephemeral root modules described by Xia et al. (2010). During excision, they were only damaged at the locations where the intact root networks were detached.

For all root classes, a sample of approximately $2-5 \mathrm{~g}$ fresh weight was placed in a respiration cuvette attached to an IRGA (CIRAS-2 portable gas analyzer; PP Systems, Haverhill, MA, USA). Respiration was measured at a $\mathrm{CO}_{2}$ concentration of $1000 \mu \mathrm{L} \mathrm{L}^{-1}$, which approximates the concentration typically found near the soil surface in northern hardwood forests (Burton \& Pregitzer, 2003). The base of the aluminum root respiration cuvette was inserted in a water bath to maintain samples at a consistent temperature of $18{ }^{\circ} \mathrm{C}$. This common temperature was used to facilitate comparisons among sites, and is typical of soil temperatures during the warmest part of the growing season in most years. Field soil temperatures at the sites on the actual measurement dates ranged from $14{ }^{\circ} \mathrm{C}$ at Site $\mathrm{A}$ to $17{ }^{\circ} \mathrm{C}$ at Site D.

After respiration measurements, all samples were kept on ice and then frozen until they could be returned to the laboratory for further analysis. In the laboratory, samples were rinsed with deionized water to remove any soil or organic matter not removed during field-cleaning, oven-dried $\left(65^{\circ} \mathrm{C}\right.$, $48 \mathrm{~h}$ ) for determination of actual sample weight, and analyzed for $\mathrm{N}$ concentration using an elemental analyzer (Carlo Erba NA 1500 NC; CE Elantech, Lakewood, NJ, USA). All specific respiration rates provided in this report are expressed on a dry weight basis.

The adhering material rinsed from the roots was captured on a screen, dried, and weighed. The mass of this material was typically $<2 \%$ of sample weight for $<0.5 \mathrm{~mm}$ roots and less than $0.5 \%$ of sample weight for larger roots. Microbial respiration in the adhering soil and organic debris would have been measured as root respiration, but rates of microbial respiration per gram of forest soil material (Zak et al., 1999) are often orders of magnitude less than those we measured per gram of root tissue. Thus, the contribution of these materials to measured root respiration rates should be a very minor fraction of the reported values.

Live root biomass was determined with samples from three random locations in each plot receiving ambient or experimental $\mathrm{N}$ deposition, collected during August using the same procedures and depths used to collect samples for root respiration. These soil samples were frozen and taken to the lab, where roots later were sorted from the cores by hand and placed into one of five diameter classes: $<0.5,0.5-1,1-2,2-5$, and $5-10 \mathrm{~mm}$. For this report, masses from the $2-5$ and 5 $10 \mathrm{~mm}$ classes were combined into a common $2-10 \mathrm{~mm}$ class that corresponded to the same diameter class used for determining specific root respiration rate and root $\mathrm{N}$ concentration. Root mass was determined after oven drying for $48 \mathrm{~h}$ at $65{ }^{\circ} \mathrm{C}$. The residual soil from one-third of the cores was elutriated (Hydropneumatic Root Washer; Gillison's Variety Fabrication, Benzonia, MI, USA) to capture very fine roots that were missed by hand-sorting (Smucker et al., 1982) and determine correction factors for adjusting the $<0.5 \mathrm{~mm}$ masses from hand-sorting to account for all roots within the class contained in a core. The elutriated root slurry was placed in a clear plastic tray with a grid pattern on the bottom. This was then placed on a light table, and the total number of line intercepts recorded. For a subset of these samples, all elutriated very fine roots $(<0.5 \mathrm{~mm})$ were retrieved by hand from the line-intercept tray, dried, and weighed. This allowed us to develop a relationship between line-intercept count and very fine root mass, which was used to convert all line-intercept counts to masses. Across sites, an average of $40 \%$ of very fine root biomass was not captured by hand-sorting.

The $\mathrm{CO}_{2}$ flux $\left(\mathrm{g} \mathrm{C} \mathrm{m}^{-2}\right)$ from whole-root-system respiration at $18{ }^{\circ} \mathrm{C}$ was determined by multiplying specific respiration rates for each root class by the corresponding biomass for that class. These were then summed to estimate whole-root-system respiration by treatment and site.

Four-factor analysis of variance was used to assess the influences of $\mathrm{N}$ addition, study site, root diameter and soil depth on specific root respiration rate, root $\mathrm{N}$ concentration, root biomass, and the components of whole-root-system respiratory flux. Relationships between root $\mathrm{N}$ concentration and specific respiration rate at $18{ }^{\circ} \mathrm{C}$ for the ambient and chronic $\mathrm{N}$ deposition treatments were further examined through linear regression, with a separate relationship developed for each treatment. We then assessed possible errors that could result by assuming that the ambient root respiration-N concentration relationship was valid for the chronic $\mathrm{N}$ deposition treatment. To do this, we used the respiration- $\mathrm{N}$ regression relationships from each treatment to estimate respiration for each combination of root size class and depth at each site. These values were summed to derive predictions of root system respiration for the chronic $\mathrm{N}$ deposition treatment, which were then compared with the actual measured values.

\section{Results}

Root $\mathrm{N}$ and specific respiration rate were greater for smaller diameter roots and roots at shallow depths (Fig. 1a,b; Table 2). The decrease in both $\mathrm{N}$ and specific respiration rate with depth was much less pronounced for larger diameter roots, leading to significant depth by size class interactions. There were also differences among sites, with Site B tending to have higher root $\mathrm{N}$ and respiration rates, especially for very fine surface roots. Root nitrogen concentrations have increased significantly in response to a decade and a half of the chronic $\mathrm{N}$ deposition treatment, particularly for roots of the larger size classes. This response occurred at all sites, but was strongest at Sites A and C, leading to a significant site by treatment interaction. Despite the large increases in root $\mathrm{N}$ concentration with $\mathrm{N}$ deposition for many size classes and depths, root respiration 

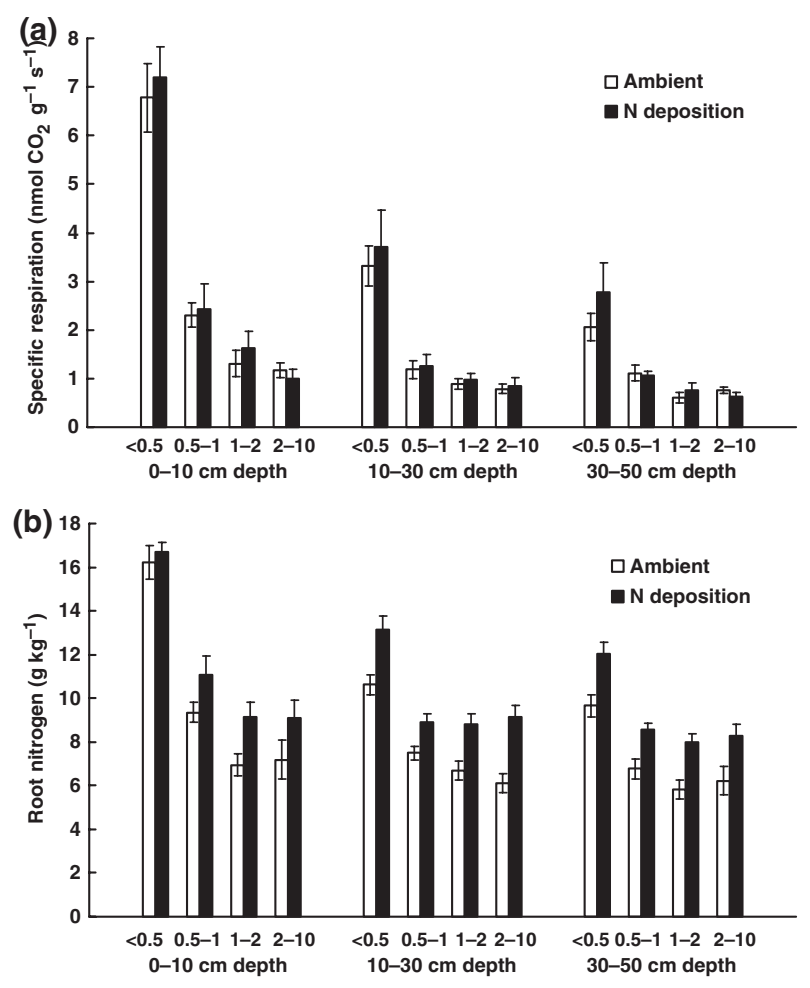

deposition treatment (Fig. 1c; Table 3) and differed only marginally among sites.

Given the lack of chronic N deposition effects on both specific root respiration and root biomass, it is not surprising that their product, whole-root-system respiration, also was not affected by this treatment (Fig. 3; Table 3). In aggregate, all roots to a depth of $50 \mathrm{~cm}$ produced an average respiratory $\mathrm{C}$ flux of $3.2 \mu \mathrm{mol} \mathrm{m}{ }^{-2} \mathrm{~s}^{-1}$ at $18^{\circ} \mathrm{C}$. Differences did exist among root size classes and depths in their contributions to whole-root-system respiration, with very fine surface roots contributing a much greater proportion (53\%) than any other size class-soil depth combination. Very fine roots, in general, were quite active, and across all depths contributed $69 \%$ of the whole-root-system respiration, despite comprising only $27 \%$ of total root biomass.

\section{Discussion}

\section{Chronic $N$ deposition effects}

The significant increase in $\mathrm{N}$ concentration in response to chronic $\mathrm{N}$ deposition found for all roots, except very fine surface roots $(<0.5 \mathrm{~mm}, 0-10 \mathrm{~cm}$ depth), differs from results in the early years of the study, when experimental $\mathrm{N}$ deposition affected neither root $\mathrm{N}$ concentration nor specific respiration rates for any size class or depth (Pregitzer et al., 1998). As a result, the relationship between root specific respiration rate and $\mathrm{N}$ concentration differs for the ambient and chronic $\mathrm{N}$ deposition treatments. This finding, after long-term (15 + years) $\mathrm{N}$ additions, is in contrast to our findings in 1996, the third year of treatment, when a common relationship existed across both treatments (Fig. 4). The altered respiration-N relationship for larger diameter and deeper roots in 2009 may indicate storage of excess $\mathrm{N}$ in compounds including amino acids and proteins (Bauer et al., 2004), or it could be the result of potentially active protein or amino $\mathrm{N}$ that does result in higher respiration due to substrate limitations or adenylate control (Atkin \& Tjoelker, 2003). For the coarse roots, in particular, we believe increased $\mathrm{N}$ storage is the most likely cause. The delay in this response of several years following initiation of the $\mathrm{N}$ deposition treatment may be due to the time needed for $\mathrm{N}$ additions to saturate microbial and plant $\mathrm{N}$ demand, allowing for accumulation and storage of excess $\mathrm{N}$ in tree roots to occur. Large increases in soil solution $\mathrm{NO}_{3}^{-}$and dissolved organic $\mathrm{N}$ concentrations at a depth of $75 \mathrm{~cm}$ at the sites did not begin until after the 1996 growing season, indicating that the sites were not $\mathrm{N}$-saturated prior to that time. Since the year 2000, more than $70 \%$ N added annually leaches from the study sites (Pregitzer et al., 2004). 
Table 2 Analysis of variance for the effects of chronic $\mathrm{N}$ deposition $\left(3 \mathrm{~g} \mathrm{~N} \mathrm{~m}^{-2} \mathrm{yr}^{-1}\right)$ on specific root respiration rate $\left(\mathrm{nmol} \mathrm{g}{ }^{-1} \mathrm{~s}^{-1}\right)$ and root $\mathrm{N}$ concentration $\left(\mathrm{g} \mathrm{kg}^{-1}\right)$ for four northern hardwood study sites in Michigan

\begin{tabular}{|c|c|c|c|c|c|c|c|}
\hline \multirow[b]{2}{*}{ Source } & \multirow[b]{2}{*}{ df } & \multicolumn{3}{|c|}{ Root respiration } & \multicolumn{3}{|c|}{ Root $\mathrm{N}$ concentration } \\
\hline & & Mean-square & F-ratio & $P$ & Mean-square & $F$-ratio & $P$ \\
\hline Treatment & 1 & 1.98 & 1.74 & 0.189 & 2.83 & 88.90 & $<0.001$ \\
\hline Site & 3 & 13.76 & 12.04 & $<0.001$ & 0.50 & 15.66 & $<0.001$ \\
\hline Depth & 2 & 81.35 & 71.19 & $<0.001$ & 1.67 & 52.59 & $<0.001$ \\
\hline Size class & 3 & 186.04 & 162.80 & $<0.001$ & 4.82 & 151.59 & $<0.001$ \\
\hline Treatment $\times$ site & 3 & 0.53 & 0.46 & 0.710 & 0.12 & 3.81 & 0.011 \\
\hline Treatment $\times$ depth & 2 & 0.00 & 0.00 & 0.998 & 0.03 & 0.98 & 0.376 \\
\hline Treatment $\times$ size class & 3 & 1.17 & 1.03 & 0.382 & 0.02 & 0.58 & 0.627 \\
\hline Site $\times$ depth & 6 & 2.08 & 1.82 & 0.097 & 0.01 & 0.44 & 0.853 \\
\hline Site $\times$ size class & 9 & 6.78 & 5.94 & $<0.001$ & 0.04 & 1.33 & 0.223 \\
\hline Depth $\times$ size class & 6 & 24.03 & 21.03 & $<0.001$ & 0.35 & 10.93 & $<0.001$ \\
\hline Treatment $\times$ site $\times$ depth & 6 & 1.74 & 1.52 & 0.173 & 0.03 & 0.80 & 0.572 \\
\hline Treatment $\times$ site $\times$ size class & 9 & 0.77 & 0.67 & 0.735 & 0.06 & 1.76 & 0.079 \\
\hline Treatment $\times$ depth $\times$ size class & 6 & 0.13 & 0.12 & 0.994 & 0.02 & 0.74 & 0.617 \\
\hline Site $\times$ depth $\times$ size class & 18 & 1.06 & 0.93 & 0.549 & 0.02 & 0.52 & 0.949 \\
\hline Treatment $\times$ site $\times$ depth $\times$ size class & 18 & 0.83 & 0.72 & 0.784 & 0.02 & 0.75 & 0.758 \\
\hline Error & 192 & 1.14 & & & 0.03 & & \\
\hline
\end{tabular}

$P$ values $<0.05$ are highlighted in bold type.

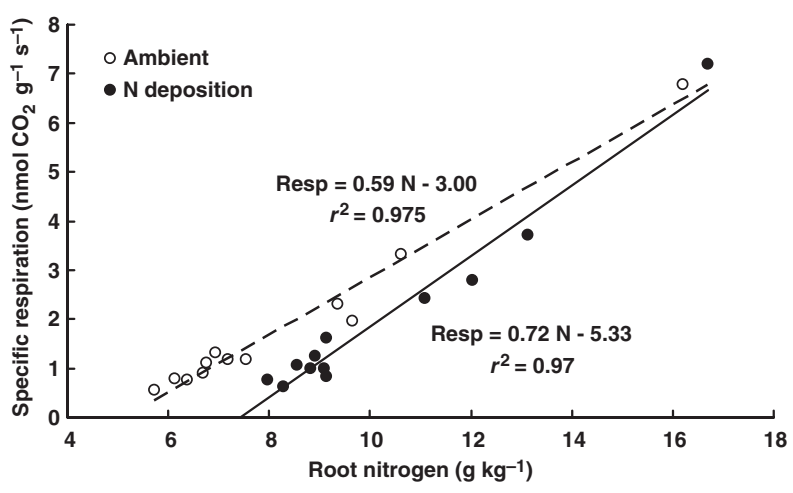

Fig. 2 Relationship between root $\mathrm{N}$ concentration and specific root respiration rate at $18{ }^{\circ} \mathrm{C}$ for the ambient and chronic $\mathrm{N}$ deposition treatments in 2009. Data points represent the average value $(n=12)$ of three plots per treatment at four northern hardwood study sites for each of the 12 combinations of root diameter class and soil depth illustrated in Fig. 1. Relationships between root $\mathrm{N}$ and specific respiration rate differed significantly for the control and chronic $\mathrm{N}$ addition treatments.

The 2009 sampling is the first comprehensive set of root respiration measurements that has shown an altered respiration- $\mathrm{N}$ relationship for our study sites, but it should be noted that the measurements between 1996 and 2009, which showed no effect of the chronic N deposition treatment, were focused on surface fine roots (Burton \& Pregitzer, 2003; Burton et al., 2004). This root class still did not show $\mathrm{N}$ deposition effects for specific respiration or root N concentration in 2009
(Fig. 1a,b). Therefore, the time point at which excess $\mathrm{N}$ began accruing in deeper, coarse roots cannot be determined precisely.

Our results are for a long-term response to relatively moderate chronic $\mathrm{N}$ inputs $\left(3 \mathrm{~g} \mathrm{~N} \mathrm{~m}^{-2} \mathrm{yr}^{-1}\right)$. In some cases, similar findings have been reported for shorterterm $\mathrm{N}$ additions at higher rates. For example, Jia et al. (2010) found that specific respiration and N concentration both increased for surface roots $(0-10 \mathrm{~cm}$ depth, $<2 \mathrm{~mm}$ diameter, most $<0.5 \mathrm{~mm}$ ) in larch [Larix gmelinii Rupr.(Rupr.)] and ash (Fraxinus mandshurica Rupr.) plantations that had received $10 \mathrm{~g} \mathrm{~N} \mathrm{~m}^{-2} \mathrm{yr}^{-1}$ for 4 years. For the larch, the increase in respiration was less than the increase in root $\mathrm{N}$, leading to a $13 \%$ reduction in the respiration : $\mathrm{N}$ concentration ratio. Unlike our study, they also found significant decreases in fine root biomass, and these were great enough that the $\mathrm{CO}_{2}$ flux from fine root respiration was lower with $\mathrm{N}$ addition than for the control for both species.

Reductions in root biomass often have been reported for $\mathrm{N}$ addition studies in forests, especially those using higher rates of $\mathrm{N}$ inputs, in the range of 5$15 \mathrm{~g} \mathrm{~N} \mathrm{~m}^{-2} \mathrm{yr}^{-1}$ (Haynes \& Gower, 1995; Magill et al., 2004; Jia et al., 2010). Our contrasting finding of no change in root biomass with chronic $\mathrm{N}$ deposition has remained consistent for five samplings since 1994 (see Burton et al., 2004). However, in agreement with the effect others have observed for increased $\mathrm{N}$ availability, the biomass of the entire belowground root-mycorrhizal absorbing network has declined at our sites, with the reduction in our case occurring in mycorrhizal 
Table 3 Analysis of variance for the effects of chronic $\mathrm{N}$ deposition $\left(3 \mathrm{~g} \mathrm{~N} \mathrm{~m}^{-2} \mathrm{yr}^{-1}\right)$ on root biomass $\left(\mathrm{g} \mathrm{m}^{-2}\right)$ and the components of whole-root-system respiration $\left(\mu \mathrm{mol} \mathrm{m} \mathrm{m}^{-2} \mathrm{~s}^{-1}\right)$ for four northern hardwood study sites in Michigan

\begin{tabular}{|c|c|c|c|c|c|c|c|}
\hline \multirow[b]{2}{*}{ Source } & \multirow[b]{2}{*}{$\mathrm{df}$} & \multicolumn{3}{|l|}{ Root biomass } & \multicolumn{3}{|c|}{ Whole-root-system respiration } \\
\hline & & Mean-square & F-ratio & $P$ & Mean-square & $F$-ratio & $P$ \\
\hline Treatment & 1 & 9732 & 0.91 & 0.342 & 0.06 & 2.02 & 0.157 \\
\hline Site & 3 & 25775 & 2.41 & 0.069 & 0.32 & 10.30 & $<0.001$ \\
\hline Depth & 2 & 95627 & 8.93 & $<0.001$ & 4.95 & 161.55 & $<0.001$ \\
\hline Size class & 3 & 632696 & 59.08 & $<0.001$ & 7.22 & 235.66 & $<0.001$ \\
\hline Treatment $\times$ site & 3 & 5728 & 0.54 & 0.659 & 0.06 & 1.79 & 0.150 \\
\hline Treatment $\times$ depth & 2 & 8543 & 0.80 & 0.452 & 0.02 & 0.52 & 0.597 \\
\hline Treatment $\times$ size class & 3 & 7546 & 0.71 & 0.550 & 0.01 & 0.47 & 0.702 \\
\hline Site $\times$ depth & 6 & 15862 & 1.48 & 0.186 & 0.18 & 5.91 & $<0.001$ \\
\hline Site $\times$ size class & 9 & 29860 & 2.79 & 0.004 & 0.38 & 12.47 & $<0.001$ \\
\hline Depth $\times$ size class & 6 & 123448 & 11.53 & $<0.001$ & 3.93 & 128.11 & $<0.001$ \\
\hline Treatment $\times$ site $\times$ depth & 6 & 9548 & 0.89 & 0.502 & 0.07 & 2.36 & 0.032 \\
\hline Treatment $\times$ site $\times$ size class & 9 & 10060 & 0.94 & 0.492 & 0.02 & 0.67 & 0.733 \\
\hline Treatment $\times$ depth $\times$ size class & 6 & 8083 & 0.76 & 0.606 & 0.01 & 0.28 & 0.948 \\
\hline Site $\times$ depth $\times$ size class & 18 & 6989 & 0.65 & 0.854 & 0.15 & 4.88 & $<0.001$ \\
\hline Treatment $\times$ site $\times$ depth $\times$ size class & 18 & 5629 & 0.53 & 0.944 & 0.04 & 1.39 & 0.140 \\
\hline Error & 192 & 10709 & & & 0.03 & & \\
\hline
\end{tabular}

$P$ values $<0.05$ are highlighted in bold type.

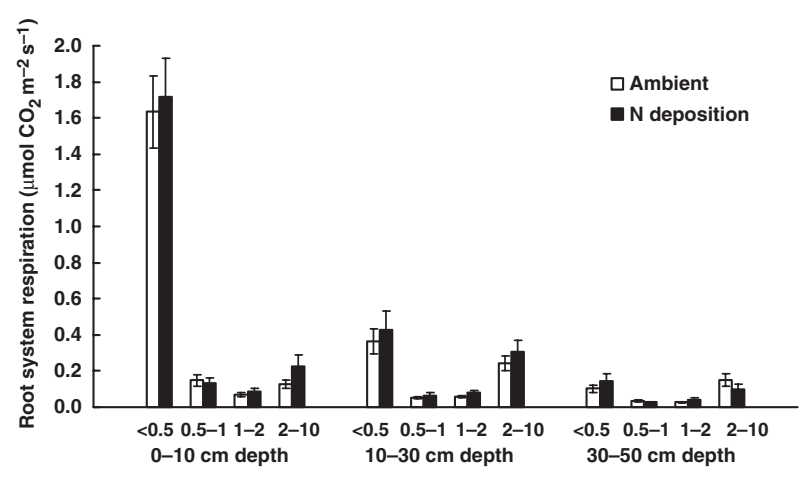

Fig. 3 Components of whole-root system respiration by soil depth and root diameter $(\mathrm{mm})$ for the ambient and chronic $\mathrm{N}$ deposition treatments. Values are the mean and standard error $(n=12)$ for three plots per treatment from each of four northern hardwood study sites.

hyphae (van Diepen et al., 2007; van Diepen et al., 2010) rather than fine root biomass.

Very fine roots in surface soil contributed $53 \%$ of whole-root-system respiration for both treatments (Fig. 3), despite having only $16 \%$ of root biomass (Fig. 1c), illustrating the importance of this root class in forest $\mathrm{C}$ allocation and cycling. The remainder of ecosystem root respiration came from the larger diameter and deeper roots for which the respiration- $\mathrm{N}$ relationship was altered by our chronic $\mathrm{N}$ deposition treatment (Fig. 2). This could lead to significant errors in calculated root system respiration, if the respiration- $\mathrm{N}$ relationship for our ambient treatment was assumed to be valid for the chronic $\mathrm{N}$ deposition treatment. Across

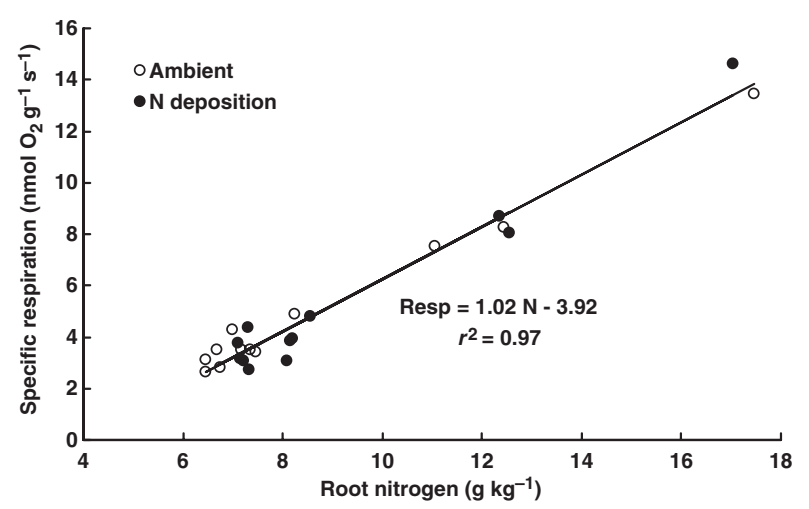

Fig. 4 Relationship between root $\mathrm{N}$ concentration and specific root respiration rate at $24{ }^{\circ} \mathrm{C}$ for the ambient and chronic $\mathrm{N}$ deposition treatments in 1996. Data points represent the average value $(n=6)$ of three plots per treatment at two study sites (sites A and B) for each of the 12 combinations of root diameter class and soil depth. Relationships between root $\mathrm{N}$ and specific respiration in 1996 did not differ for the control and chronic N addition treatments. Data are from Pregitzer et al. (1998).

the four study sites, whole-root-system respiration at $18{ }^{\circ} \mathrm{C}$ predicted for the $\mathrm{N}$ deposition treatment using the ambient respiration- $\mathrm{N}$ relationship is $41 \%$ greater than that predicted using the relationship for the $\mathrm{N}$ deposition treatment and 50\% greater than the actual measured value (Table 4). Both relationships accurately predicted the respiratory flux from surface very fine roots, but large over-predictions, as great as 291\%, occurred for other root classes, especially the largest diameter roots (Table 4). Bauer et al. (2004) found a 
similar decoupling for tissue $\mathrm{N}$ concentration and photosynthetic rate in red pine that had received $15 \mathrm{~g} \mathrm{~N} \mathrm{~m}^{-2} \mathrm{yr}^{-1}$ for 15 years. In their experiment, using the control plot tissue $\mathrm{N}$ relationships to model $\mathrm{C}$ cycling for the high $\mathrm{N}$ plots led to large errors, such as predictions of a $25-50 \%$ increase in wood production in response to the excessive $\mathrm{N}$ additions, instead of the actual measured decline.

Differences among sites for specific root respiration rates and $\mathrm{N}$ concentration (Table 2 ) include a trend for higher root $\mathrm{N}$ concentration and specific respiration rates at Site C and especially Site B (data not shown). These inherent site differences are in agreement with previous findings for surface very fine roots at these sites (Burton et al., 1998; Burton et al., 2004) and cooccur with higher leaf litter $\mathrm{N}$ for the ambient treatment (Pregitzer et al., 1992) and inherent soil $\mathrm{N}$ mineralization potential, as discussed in Zogg et al. (1996). Despite these pre-existing inherent differences among individual sites, our consistent finding at all sites of higher $\mathrm{N}$ concentrations in larger diameter and deeper roots for the chronic $\mathrm{N}$ deposition treatment suggests that sufficient atmospheric $\mathrm{N}$ inputs have the potential to alter the respiration-tissue $N$ relationship throughout the region for this common forest type.

\section{Root diameter and depth effects}

The significant declines in root respiration rate with increasing root diameter and depth at all four sites are in full agreement with our earlier work at Sites A and B (Pregitzer et al., 1998). Similar effects of soil depth on root $\mathrm{N}$ concentration have been documented for subalpine fir forests (Abies mariesii Masters and Abies veitchii Lindl.; Ugawa et al., 2010). Lower respiration and $\mathrm{N}$ concentration for larger diameter roots also agrees with findings of others for roots from 2 to $45 \mathrm{~mm}$ for aspen (Populus tremuloides Michx.; Desrochers et al., 2002) and Eucalyptus (Marsden et al., 2008), and with increases in respiration with decreasing diameter within the $<2 \mathrm{~mm}$ class reported for F. mandshurica (Xia et al., 2010). The differences with depth and size class are probably associated with differences in root function, with higher $\mathrm{N}$ concentration and specific respiration rates occurring in surface very fine roots, which are actively involved in nutrient uptake and assimilation. Deeper fine roots at these sites are in locations with much lower overall availability of nutrients and may be primarily associated with uptake of different resources than surface fine roots (e.g. $\mathrm{Ca}^{2+}$ at depth vs. $\mathrm{N}$ forms near the surface, da Silva et al., 2011). Coarser roots with secondary development are known to not be involved in active uptake (Guo et al., 2008), but rather serve primarily as conduits for transport of water and nutrients (Wells \& Eissenstat, 2003) and for anchorage and storage. As a result, lower $\mathrm{N}$ concentrations and respiratory activity are expected for these roots, which do not have the primary function of active nutrient acquisition.

Classifications using sufficiently fine divisions of root diameter, or using root order, have often been used in

Table 4 Comparison of measured and estimated components of whole-root-system respiration $\left(\mu \mathrm{mol} \mathrm{m}^{-2} \mathrm{~s}^{-1}\right)$ at $18{ }^{\circ} \mathrm{C}$ for the ambient and chronic $\mathrm{N}$ deposition treatments. Estimates were made using the respiration-N relationships for the ambient and chronic $\mathrm{N}$ deposition treatments depicted in Fig. 2. The percent error using the ambient relationship to predict respiration for the chronic $\mathrm{N}$ deposition treatment is relative to the actual measured values for chronic $\mathrm{N}$ deposition

\begin{tabular}{|c|c|c|c|c|c|}
\hline \multirow[b]{2}{*}{$\begin{array}{l}\text { Depth } \\
(\mathrm{cm})\end{array}$} & \multirow[b]{2}{*}{$\begin{array}{l}\text { Size class } \\
(\mathrm{mm})\end{array}$} & \multicolumn{3}{|c|}{ Root system respiration $\left(\mu \mathrm{mol} \mathrm{m} \mathrm{m}^{-2} \mathrm{~s}^{-1}\right)$} & \multirow[b]{2}{*}{$\begin{array}{l}\text { Error (\%) using } \\
\text { ambient } \\
\text { relationship }\end{array}$} \\
\hline & & $\begin{array}{l}\text { Measured } \\
\text { values }\end{array}$ & $\begin{array}{l}\text { Estimated } \\
\text { from chronic } \\
\mathrm{N} \text { relationship }\end{array}$ & $\begin{array}{l}\text { Estimated } \\
\text { from ambient } \\
\text { relationship }\end{array}$ & \\
\hline $0-10$ & $<0.5$ & 1.720 & 1.659 & 1.699 & -1 \\
\hline $0-10$ & $0.5-1$ & 0.135 & 0.147 & 0.197 & 46 \\
\hline $0-10$ & $1-2$ & 0.089 & 0.078 & 0.148 & 67 \\
\hline $0-10$ & $2-10$ & 0.226 & 0.282 & 0.548 & 142 \\
\hline $10-30$ & $<0.5$ & 0.428 & 0.437 & 0.504 & 18 \\
\hline $10-30$ & $0.5-1$ & 0.066 & 0.056 & 0.118 & 79 \\
\hline $10-30$ & $1-2$ & 0.079 & 0.082 & 0.177 & 122 \\
\hline $10-30$ & $2-10$ & 0.305 & 0.487 & 0.924 & 203 \\
\hline $30-50$ & $<0.5$ & 0.147 & 0.166 & 0.205 & 39 \\
\hline $30-50$ & $0.5-1$ & 0.027 & 0.023 & 0.056 & 106 \\
\hline $30-50$ & $1-2$ & 0.042 & 0.021 & 0.089 & 110 \\
\hline $30-50$ & $2-10$ & 0.099 & 0.129 & 0.385 & 291 \\
\hline Total & All & 3.362 & 3.568 & 5.048 & 50 \\
\hline
\end{tabular}


attempts to relate measured root physiological responses to function. However, such classifications do not fully account for the variation in root activity and function occurring throughout the entire soil profile, as roots of similar diameter or branch order at different depths can differ greatly in biochemical and physiological characteristics. This is illustrated by the large differences with depth among $<0.5 \mathrm{~mm}$ roots in $\mathrm{N}$ concentration and respiration rate (Fig. 1a,b), and similar, but less pronounced trends with depth for larger diameter roots. For the $<0.5 \mathrm{~mm}$ roots at these sites, differences with depth in demography have also been observed that appear to be related to root function. Deeper very fine roots had slightly shorter median lifespans, and evidence suggested that occasional occurrences of mid-summer deep root production were related to periods of severe soil water deficit (Hendrick \& Pregitzer, 1996).

For coarse roots, some have found diameter to be an equal or better predictor of respiration than $\mathrm{N}$ concentration (Marsden et al., 2008; Chen et al., 2010), but when depth is also considered, as in this study, it is apparent that respiration rates are not constant for a given coarse root diameter (Fig. 1a; significant depth effects and depth $\times$ size class interaction in Table 2). Clearly, root depth also must be considered when attempting to sample roots for assessment of their physiological activity or function.

\section{Modeling implications}

Strong relationships between plant tissue $\mathrm{N}$ and respiration have led some to suggest that tissue $\mathrm{N}$ content could be used to model respiration (Tjoelker et al., 2005), but our results indicate that linear relationships between root respiration and $\mathrm{N}$ concentration can shift if soil $\mathrm{N}$ availability is greatly increased, as was the case for the chronic $\mathrm{N}$ deposition treatment in this experiment. In our study, the relationship changed enough that using the pre-existing relationship for the ambient treatment would have resulted in an overestimate of the $\mathrm{CO}_{2}$ efflux from whole-root-system respiration of $50 \%$. If such an estimate were included in a model of ecosystem $\mathrm{C}$ cycling, the amount of $\mathrm{C}$ available for allocation to other uses would have been reduced by an equivalent amount, potentially leading to significant underestimates of factors such as biomass production and overestimates of the flux of $\mathrm{CO}_{2}$ from soil to the atmosphere. Although there are many instances for which tissue $\mathrm{N}$ is a good predictor of respiration rate, our results are in agreement with those who have cautioned against its use in modeling due to variation in relationships among species and tissues (Gifford, 2003). It has been suggested that a conservative respiration to photosynthesis ratio (Gifford, 2003) or a variable, but constrained, range of this ratio (Cannell \& Thornley, 2000) might work best for modeling respiration at the whole plant or ecosystem level in a global change context. We believe that attempts to model root system respiration for significantly altered conditions should heed such constraints.

\section{Acknowledgements}

We thank Rachel McDonald, Jennifer Eikenberry, Gabrielle Trudeau, Andrew Beebe, Ofori Lartey, and Alisha Autio for their help in the field and lab. This research was supported by the National Science Foundation under grants DEB 0814623, 0814864, and 1059720 and a Research Experiences for Undergraduate supplement to DEB 0814864 .

\section{References}

Amthor JS (2000) The McCree-de Wit-Penning de Vries-Thornley respiration paradigms: 30 years later. Annals of Botany, 86, 1-20.

Atkin OK, Tjoelker MG (2003) Thermal acclimation and the dynamic response of plant respiration to temperature. Trends in Plant Science, 8, 343-351.

Atkinson LJ, Hellicar MA, Fitter AH, Atkin OK (2007) Impact of temperature on the relationship between respiration and nitrogen concentration in roots: an analysis of scaling relationships, $\mathrm{Q}_{10}$ values and thermal acclimation ratios. New Phytologist, 173, 110-120.

Bakker MR, Jolicoeur E, Trichet P, Augusto L, Plassard C, Guinberteau J, Loustau D (2009) Adaptation of fine roots to annual fertilization and irrigation in a 13-yearold Pinus pinaster stand. Tree Physiology, 29, 229-238.

Bauer GA, Bazzaz FA, Minocha R, Long S, Magill A, Aber J, Berntson GM (2004) Effects of chronic $\mathrm{N}$ additions on tissue chemistry, photosynthetic capacity, and carbon sequestration potential of a red pine (Pinus resinosa Ait.) stand in the NE United States. Forest Ecology and Management, 196, 173-186.

Burton AJ, Pregitzer KS (2003) Field measurements of root respiration indicate little to no seasonal temperature acclimation for sugar maple and red pine. Tree Physiology, 23, 273-280.

Burton AJ, Pregitzer KS, Zogg GP, Zak DR (1996) Latitudinal variation in sugar maple fine root respiration. Canadian Journal of Forest Research, 26, 1761-1768.

Burton AJ, Pregitzer KS, Zogg GP, Zak DR (1998) Drought reduces root respiration in sugar maple forests. Ecological Applications, 8, 771-778.

Burton AJ, Pregitzer KS, Hendrick RL (2000) Relationships between fine root dynamics and nitrogen availability in Michigan northern hardwood forests. Oecologia, 125, 389-399.

Burton AJ, Pregitzer KS, Ruess RW, Hendrick RL, Allen MF (2002) Root respiration in North American forests: effects of nitrogen concentration and temperature across biomes. Oecologia, 131, 559-568.

Burton AJ, Pregitzer KS, Crawford JN, Zogg GP, Zak DR (2004) Simulated chronic $\mathrm{NO}_{3}{ }^{-}$deposition reduces soil respiration in northern hardwood forests. Global Change Biology, 10, 1080-1091.

Cannell MGR, Thornley JHM (2000) Modelling the components of plant respiration: some guiding principles. Annals of Botany, 85, 45-54.

Chen DM, Zhou LX, Rao XQ, Lin YB, Fu SL (2010) Effects of root diameter and root nitrogen concentration on in situ root respiration among different seasons and tree species. Ecological Research, 25, 983-993.

Desrochers A, Landhäusser SM, Liefers VJ (2002) Coarse and fine root respiration in aspen (Populus tremuloides). Tree Physiology, 22, 725-732.

van Diepen LTA, Lilleskov EA, Pregitzer KS, Miller RM (2007) Decline of arbuscular mycorrhizal fungi in northern hardwood forests exposed to chronic nitrogen amendments. New Phytologist, 176, 175-183.

van Diepen LTA, Lilleskov EA, Pregitzer KS, Miller RM (2010) Simulated nitrogen deposition causes a decline of intra- and extraradical abundance of arbuscular mycorrhizal fungi and changes in microbial community structure in northern hardwood forests. Ecosystems, 13, 683-695.

Gifford RM (2003) Plant respiration in productivity models: conceptualisation, representation and issues for global terrestrial carbon-cycle research. Functional Plant Biology, 30, 171-186. 
Guo DL, Xia MX, Wei X, Change WJ, Liu Y, Wang ZQ (2008) Anatomical traits associated with absorption and mycorrhizal colonization are linked to root branch order in twenty-three Chinese temperate tree species. New Phytologist, 180, 673-683.

Hanson PJ, Amthor JS, Wullschleger SD et al. (2004) Oak forest and water simulations: model intercomparisons and evaluations against independent data. Ecological Monographs, 74, 443-489.

Haynes BE, Gower ST (1995) Belowground carbon allocation in unfertilized and fertilized plantations in northern Wisconsin. Tree Physiology, 15, 317-325.

Hendrick RL, Pregitzer KS (1992) The demography of fine roots in a northern hardwood forest. Ecology, 73, 1094-1104.

Hendrick RL, Pregitzer KS (1996) Temporal and depth-related patterns of fine root dynamics in northern hardwood forests. Journal of Ecology, 84, 167-176.

Jia SX, Wang ZQ, Li XP, Sun Y, Zhang XP, Liang AZ (2010) N fertilization affects on soil respiration, microbial biomass and root respiration in Larix gmelinii and Fraxinus mandshurica plantations in China. Plant and Soil, 333, 325-336.

Jurgensen MF, Larsen MJ, Harvey AE (1977) A Soil Sampler for Steep, Rocky Sites. USDA Forest Service Research Note INT-RN-217.

MacDonald NW, Burton AJ, Liechty HO et al. (1992) Ion leaching in forest ecosystems along a Great Lakes air pollution gradient. Journal of Environmental Quality, 21, 614-623.

Magill AH, Aber JD, Berntson GM, McDowell WH, Nadelhoffer KJ, Melillo JM, Steudler $\mathrm{P}$ (2000) Long-term nitrogen additions and nitrogen saturation in two temperate forests. Ecosystems, 3, 238-253.

Magill AH, Aber JD, Currie WS et al. (2004) Ecosystem response to 15 years of chronic nitrogen additions at the Harvard Forest LTER, Massachusetts, USA. Forest Ecology and Management, 196, 7-28.

Marsden C, Nouvelloni Y, Epron D (2008) Relating coarse root respiration to root diameter in clonal Eucalyptus stands in the Republic of the Congo. Tree Physiology, 28, 1245-1254.

Melillo JM, Steudler PA, Aber JD et al. (2002) Soil warming and carbon-cycle feedbacks to the climate system. Science, 298, 2173-2176.

Melillo JM, Butler S, Johnson J et al. (2011) Soil warming, carbon-nitrogen interactions and forest carbon budgets. Proceedings of the National Academy of Sciences, 108, 9508-9512.

Pregitzer KS, Burton AJ, Mroz GD, Liechty HO, MacDonald NW (1992) Foliar sulfur and nitrogen along an $800-\mathrm{km}$ pollution gradient. Canadian Journal of Forest Research, 22, 1761-1769.

Pregitzer KS, Laskowski MJ, Burton AJ, Lessard VC, Zak DR (1998) Variation in sugar maple root respiration with root diameter and soil depth. Tree Physiology, 18, 665 670.

Pregitzer KS, Zak DR, Burton AJ, Ashby JA, MacDonald NW (2004) Chronic nitrate additions dramatically increase the export of carbon and nitrogen from northern hardwood ecosystems. Biogeochemistry, 68, 179-197.
Rastetter EB, Ryan MG, Shaver GR, Melillo JM, Nadelhoffer KJ, Hobbie JE, Aber JD (1991) A general biogeochemical model describing the responses of the $\mathrm{C}$ and $\mathrm{N}$ cycles in terrestrial ecosystems to changes in $\mathrm{CO}_{2}$, climate, and $\mathrm{N}$ deposition. Tree Physiology, 9, 101-126.

Reich PB, Tjoelker MG, Pregitzer KS, Wright IJ, Oleksyn J, Machado JL (2008) Scaling of respiration to nitrogen in leaves, stems and roots of higher land plants. Ecology Letters, 11, 793-801.

Rustad LE, Campbell JL, Marion GM et al. (2001) A meta-analysis of the response of soil respiration, net nitrogen mineralization, and aboveground plant growth to experimental ecosystem warming. Oecologia, 126, 543-562.

Ryan MG, Hubbard RM, Pongracic S, Raison RJ, McMurtrie RE (1996) Foliage, fineroot, woody tissue and stand respiration in Pinus radiata in relation to nutrient stress. Tree Physiology, 16, 333-343.

da Silva EV, Bouillet J-P, Gonçalves JLM et al. (2011) Functional specialization of Eucalyptus fine roots: contrasting potential uptake rates for nitrogen, potassium and calcium tracers at varying soil depths. Functional Ecology, doi: 10.1111/j.13652435.2011.01867.x, in press.

Smucker AJM, McBurney SL, Srivanstava AK (1982) Quantitative separation of roots from compacted soil profiles by the hydropneumatic elutriation system. Agronomy Journal, 74, 500-503.

Tjoelker MG, Craine JM, Wedin D, Reich PB, Tilman D (2005) Linking leaf and root trait syndromes among 39 grassland and savannah species. New Phytologist, 167, 493-508.

Ugawa S, Miura S, Iwamoto K, Kaneko S, Fukuda K (2010) Vertical patterns of fine root biomass, morphology and nitrogen concentration in a subalpine fir-wave forest. Plant and Soil, 335, 469-478.

Wells CE, Eissenstat DM (2003) Beyond the roots of young seedlings: the influence of age and order on fine root physiology. Journal of Plant Growth Regulation, 21, 324 334.

Xia MX, Guo DL, Pregitzer KS (2010) Ephemeral root modules in Fraxinus mandshurica. New Phytologist, 188, 1065-1074.

Zak DR, Holmes WE, MacDonald NW, Pregitzer KS (1999) Soil temperature, matric potential, and the kinetics of microbial respiration and nitrogen mineralization Soil Science Society of America Journal, 63, 575-584.

Zhou Y, Tang J, Melillo JM, Butler SM, Mohan JE (2011) Fine root standing crop and chemistry after six years of soil warming in a temperate forest. Tree Physiology, 31, 707-717.

Zogg GP, Zak DR, Burton AJ, Pregitzer KS (1996) Fine root respiration in northern hardwood forests in relation to temperature and nitrogen availability. Tree Physiology, 16, 719-725. 